\title{
The Causes of Road Traffic Accidents in Hargeisa City, Somaliland
}

\author{
Mohamed Faizal (MSc) (corresponding author), Hargeisa Mossa Endris Ahmed (PhD) \\ Disaster Risk Management and Sustainable Development Department, Institute of Disaster Risk Management \\ and Food Security Studies, Bahir Dar University, P.O.Box 5501, Bahir Dar \\ Adane Tesfaye Lema (PhD) \\ Disaster Risk Management and Sustainable Development Department, Institute of Disaster Risk Management \\ and Food Security Studies, Bahir Dar University, P.O.Box 5501, Bahir Dar
}

\begin{abstract}
Road traffic accidents are the eighth leading cause of death globally, and the leading cause of death for young people aged 15-29 (productive age group). The objective of the thesis is to examine the causes of road traffic accidents in Hargeisa City. Both primary and secondary data sources were used. Primary data was collected from a sample of pedestrians and drivers by using a questionnaire and field observation. Also, archival documents and interviews with key informants from the Hargeisa traffic police. About 144 sample pedestrians and 80 sample drivers were drawn from a sampling frame of pedestrians and drivers using a purposive sampling technique. The data was analyzed through both descriptive and inferential statistics and narration for quantitative and qualitative information, respectively. According to the findings of the chi-square test, the following factors are associated with road traffic accidents in Hargeisa city: drivers age (0.001), driver's speed (0.003), failure to give pedestrians priority to pass first as required by law (0.027), use of mobile phones (0.008), and non-use of seat belts $(0.009)$, drivers violating traffic rules and regulations (0.015). As the main contributing factors to road traffic accidents in the city. The study recommended that unless immediate actions to revert the problem are taken, it will worsen in the future as motorization and the population of the city grow altogether.
\end{abstract}

Keywords: Causes, Road Traffic Accidents, Pedestrians, Drivers, Hargeisa, Somaliland

DOI: $10.7176 /$ RHSS/12-3-03

Publication date: February $28^{\text {th }} 2022$

\section{Introduction}

\subsection{Background of the study}

The African Region continues to have the highest road traffic death rates (WHO, 2015). The condition of road traffic accidents is most severe in Sub-Saharan Africa, where the lives of millions are lost and a significant amount of property is damaged (WHO, 2021). According to the study, social and economic costs of road traffic accidents are also high; when productivity loss and expenses incurred were measured, the world is losing $\$ 800$ billion annually, and the cost in the developing world was estimated to be about $\$ 80$ million (TRL, 2010).

In Somaliland, many people due to traffic accidents die on the road and in the side of the road each year, with hundreds of people injured, vehicles damaged and properties lost in these accidents for an example, in 2016, traffic violation accidents caused 165 deaths on Somaliland roads; more than deaths caused by killing and war. In addition, traffic accidents caused 2,043 injuries; saw the damage of 1,649 vehicles, and the loss of 5,003 heads of livestock. One of the major causes of these accidents is poor general road knowledge and lack of traffic safety regulations (NDP, 2017-2021)

Most of the highways and roads in Somaliland were built long before Somaliland regained its independence in 1991 and are regarded as old-fashioned. Those roads were designed for use not more than ten or twenty years. Now, they are almost in bad conditions and pose great danger to drivers, passengers and cars (Ahmed, 2013).

According to the Abdirizak (2016) report, it was stated that from January to November, Somaliland recorded 2873 motor accidents involving 2600 vehicles. Likewise, the Traffic Unit police during this period found 156 fatalities and 1815 injury cases in road accidents. Therefore, roads are the arteries through which the economy pulses. By connecting producers to markets, workers to jobs, students to school, and the sick to hospitals, on the other hand, roads are vital to any development agenda (DIaspora, 2016).

Hargeisa is the capital city and most populated town in Somaliland. It is located on the main and busiest road that connects other parts of the country, from the Borama to the Sanaag regions. On the other hand, Hargeisa is a fast-growing city that has contributed a lot to rapid urbanization. In Hargeisa city, many road traffic accidents take place every day, with those rising from time to time. For example, about 1,251 road accidents occurred in 2004 compared to 2,199 in 2011, causing 75 injuries and 142 deaths, respectively (Said, 2012).

Therefore, in conjunction with the above facts, the study evaluated the trends, major causes, and socioeconomic costs of traffic accidents in Hargeisa City. Thus, the study can contribute by showing the intensity and constraints of road traffic accidents in the city to road users and concerned bodies.

\subsection{Statement of the problem}


Road accidents and their consequences cannot be fully eradicated, but can be reduced drastically. The decrease in accident rates comes as a result of actions on many fronts, including more disciplining of drivers and pedestrians, safer vehicles, safer roads through education, engineering, and enforcement (Ahmed \&Nimco, 2016).

There are causes for car accidents, including high speeding and mobile phones, which can result in a great loss of life and other destruction of other social and economic aspects of life, including poor road infrastructures, unqualified drivers, left-hander cars, and others who are facilitating accidents in one way or another. The study concluded that the level of car accidents in Hargeisa city is very great, particularly in recent years, which has resulted in a lot of destruction both socially and economically (Saied, 2019).

Hargeisa has become one of the leading road traffic accidents in the rest of the country. Most accidents in Hargeisa happen without clearing the lanes, which requires the driver to be marked, not allowed to pass. Therefore, the report concluded that accidents led to negligence of the driver in the Hargeisa city, not only negligence of the driver that causes the accident, but the lack of driving or the knowledge of the rules or not following the rules and don't have any clue about the rules of the road (Koshin, 2014).

In connection with the facts, traffic volume is becoming huge, and it is increasing from time to time. Parallels, road traffic accidents have increased over the years and are becoming a common day-to-day phenomenon resulting in loss of life, human suffering, destruction of properties and the environment.

However, the research gap of this study are much research has not been done to curve the problem of road traffic accident reduction in Somaliland, Hargeisa city. So far, previous studies have focused on engineering issues relating to vehicle safety. While accidents are worsening from time to time, and the road traffic rules are being violated by road users.

\subsection{Research Objective}

The general objective of the study is to analyze the causes of road traffic accidents in Hargeisa city, Somaliland.

\section{Materials and methods}

\subsection{Description of the study area}

The study was conducted in the capital city of Somaliland. Hargeisa is the city in the Marodi-jeh region of Somaliland (Haas, 2017).

Hargeisa has a semi-arid climate. the GPS coordinates of Hargeisa city are: $9^{\circ} 33^{\prime} 44.6004^{\prime \prime} \mathrm{N}$ and $44^{\circ} 4^{\prime}$ 37.2396" E and also, Latitude and longitude coordinates are: 9.562389, 44.077011. The city receives the bulk of its precipitation between the months of April and September, averaging just less than 400 millimeters (16 in) of rainfall annually. In Hargeisa, the average monthly temperature ranges from $18{ }^{\circ} \mathrm{C}\left(64{ }^{\circ} \mathrm{F}\right)$ in December and January to $24^{\circ} \mathrm{C}\left(75^{\circ} \mathrm{F}\right)$ in June.

\subsection{Methods of Data Collection}

Both primary and secondary data sources are used. Cross-sectional survey with utilization of both qualitative and quantitative approaches was used. The population is divided in to two heterogeneous groups: the road users (Pedestrians) and the one that uses their pedal for travelling from one place to the other (Drivers). Then samples are drawn rand only from these sample groups using stratified purposive sampling technique. Records of road traffic accident situations which occurred for the last five years (2015-2019) were taken from Hargeisa traffic police office for the triangulation and accomplishment of the questionnaires.

\subsection{Study site selection and Sample size determination}

Three study districts were purposively selected from Hargeisa city. The representative samples of the target people from the community groups (pedestrians and drivers) for the questionnaire survey were selected from a sampling frame of about 55127 pedestrians, which is the population of three districts, and 425 drivers. The sample size for collecting quantitative data for this research is determined by using Cochran's (1977) formula. The sample size for pedestrians was calculated using an only population proportion formula by considering the proportion of road traffic accidents as $50 \%$ and $10 \%$ margin of error.

$\mathrm{n}=\frac{z^{2} * \mathrm{p}(1-\mathrm{p})}{d^{2}}$

Where:

$>\mathrm{n}=$ Sample size required for the study.

$>\mathrm{z}=95 \%$ confidence level (1.96).

$>\mathrm{p}=$ Proportion of accidents (0.5), people expected to have the basic knowledge about the problem (occurrence of road traffic accidents in this case).

$>\mathrm{d}=$ Desired precision $(10 \%)$. 
Substituting all these values to the above Cochran formula produced a total sample size (n) of:

$$
\mathrm{n}=\frac{z^{2} * \mathrm{p}(1-2)}{\mathbb{d}^{2}}=n=\frac{1.96 x^{2} * 0.5(1-0.5)}{\left[(0.1)^{2}\right.}=96.04
$$

We use the correction formula then:

$$
\mathrm{n}=\frac{\mathrm{no}}{1+\frac{(\mathrm{nc}-1}{\pi}}=\frac{96.04}{1+\frac{(0604-1)}{55,127}}=95.874=\underline{\underline{96}}
$$

Where $\mathrm{N}=$ the total population

$\mathrm{n}=$ total number of sample size or pedestrians

Table 1: Proportion Formula of Sampled People

\begin{tabular}{|c|c|c|c|}
\hline No & Sample frame & $\mathrm{N}_{1}$ & $\mathrm{n}_{1}$ \\
\hline 1 & Pedestrians & 55,127 & $55 \rightarrow 144$ \\
\hline 2 & Drivers & 425 & 80 \\
\hline & & $\mathrm{N}=55,552$ & $\mathrm{n}=224$ \\
\hline
\end{tabular}

\subsection{Methods of Data Analysis}

Inferential statistics were used to analyze the data and interpret the results. Logistic regression was used to predict the occurrence or non-occurrence of road traffic accident based on values of a set of categorical predictor variables. The Hosmer-Lemeshow test statistic (having hypothesis of $\mathrm{H}_{0}$ : the model fits well and $\mathrm{H}_{1}$ : the model poorly fits the data) was used to indicate whether the model adequately fits the data or not. And it can be determined by comparing the $\mathrm{p}$-value at a certain df with the $\alpha$-value: if the $\mathrm{p}$-value is greater than $\alpha$-value, then there is enough evidence not to reject the null hypothesis that the model fits well otherwise not and to determine whether or not it is possible to proceed to Binary logistic regression model. The odds and odds ratio results from analysis of data by Binary logistic regression method are the basis of the test result interpretation.

\section{RESULTS AND DISCUSSION}

\subsection{Inferential statistics: Drivers' response on causes of road traffic accidents}

Inferential statistics are statistics which are used to make inferential statements about a population. These statistics rely on the use of a random sampling technique which ensures that a sample is representative of the population at large. They differ from descriptive statistics, which describe only the data itself in statistical terms (Gabrenya, 2003).

Chi-square $\left(3^{2}\right)$ test of association: The chi-square test of association assumes that for variables having $\mathbf{p}$-value less than the $\boldsymbol{\alpha}$-value (0.05), the null hypothesis can be rejected at that specified level of significance and there will be sufficient evidence to conclude that there were significant relationship between those explanatory variables and the dependent variable, otherwise not.

Hypothesis: $\left(\mathrm{H}_{0}\right.$ : There is no association between the occurrence of accident and the different independent variable categories; $\mathrm{H}_{1}$ : There is association).

Table 2. Statistical inference: Association of the occurrence of accident with different independent

\begin{tabular}{|c|c|c|c|c|c|c|c|}
\hline \multirow[t]{2}{*}{ Factor } & \multirow[t]{2}{*}{ Category } & \multirow[t]{2}{*}{$\mathrm{df}$} & \multicolumn{2}{|c|}{$\begin{array}{l}\text { Number of respondents } \\
\text { experiencing and facing road } \\
\text { traffic accidents while they are } \\
\text { driving in the city }\end{array}$} & \multirow[b]{2}{*}{ Total } & \multirow[t]{2}{*}{$\begin{array}{c}\mathrm{X}^{2}- \\
\text { value }\end{array}$} & \multirow[t]{2}{*}{$\begin{array}{l}\mathrm{P}- \\
\text { value }\end{array}$} \\
\hline & & & Yes $(\%)$ & No $(\%)$ & & & \\
\hline \multirow[t]{3}{*}{ Age } & $18-26$ years & \multirow[t]{3}{*}{3} & $16(21.4 \%)$ & $22(16.6 \%)$ & 38 & \multirow[t]{3}{*}{9.081} & \multirow[t]{3}{*}{.028} \\
\hline & $26-36$ years & & $16(14.1 \%)$ & $9(10.9 \%)$ & 25 & & \\
\hline & $35-45$ years & & $12(8.4 \%)$ & $3(6.6 \%)$ & 15 & & \\
\hline \multirow[t]{4}{*}{ Level of education } & Illiterate & \multirow{4}{*}{3} & $14(11.3 \%)$ & $6(8.8 \%)$ & 20 & \multirow[t]{4}{*}{7.169} & \multirow[t]{4}{*}{.067} \\
\hline & Primary & & $11(10.1 \%)$ & $7(7.9 \%)$ & 18 & & \\
\hline & Secondary & & $13(10.7 \%)$ & $6(8.3 \%)$ & 19 & & \\
\hline & University & & $7(12.9 \%)$ & $16(10.1 \%)$ & 23 & & \\
\hline \multirow[t]{4}{*}{ License level } & Grade A & \multirow{4}{*}{3} & $18(19.1 \%)$ & $16(14.9 \%)$ & 34 & \multirow[t]{4}{*}{9.442} & \multirow[t]{4}{*}{.024} \\
\hline & Grade B & & $7(9.0 \%)$ & $9(7.0 \%)$ & 16 & & \\
\hline & \multirow{2}{*}{$\begin{array}{l}\text { Grade C } \\
\text { None }\end{array}$} & & $4(5.1 \%)$ & $5(3.9 \%)$ & 9 & & \\
\hline & & & $16(11.8 \%)$ & $5(9.2 \%)$ & 21 & & \\
\hline
\end{tabular}
variables, 2021 


\begin{tabular}{|c|c|c|c|c|c|c|c|}
\hline \multirow[t]{2}{*}{ Factor } & \multirow[t]{2}{*}{ Category } & \multirow[t]{2}{*}{$\mathrm{df}$} & \multicolumn{2}{|c|}{$\begin{array}{l}\text { Number of respondents } \\
\text { experiencing and facing road } \\
\text { traffic accidents while they are } \\
\text { driving in the city }\end{array}$} & \multirow[b]{2}{*}{ Total } & \multirow[t]{2}{*}{$\begin{array}{c}\mathrm{X}^{2}- \\
\text { value }\end{array}$} & \multirow[t]{2}{*}{$\begin{array}{l}\text { P- } \\
\text { value }\end{array}$} \\
\hline & & & Yes $(\%)$ & No $(\%)$ & & & \\
\hline \multirow[t]{3}{*}{ Driving experience } & \multirow{3}{*}{$\begin{array}{l}1-3 \text { years } \\
4-6 \text { years } \\
7-9 \text { years }\end{array}$} & \multirow{3}{*}{3} & $13(19.1 \%)$ & $21(14.9 \%)$ & 34 & \multirow[t]{3}{*}{10.489} & \multirow[t]{3}{*}{.015} \\
\hline & & & $24(18.0 \%)$ & $8(14.0 \%)$ & 32 & & \\
\hline & & & $8(7.3 \%)$ & $5(5.7 \%)$ & 13 & & \\
\hline \multirow[t]{2}{*}{ Type of vehicle driven } & Private car & & $5(7.3 \%)$ & $8(5.7 \%)$ & 13 & \multirow[t]{2}{*}{6.545} & \multirow[t]{2}{*}{.038} \\
\hline & Commercial car & 2 & $40(36.0 \%)$ & $24(28.0 \%)$ & 64 & & \\
\hline \multirow{3}{*}{$\begin{array}{l}\text { Duration of driving the } \\
\text { particular car }\end{array}$} & \multirow{3}{*}{$\begin{array}{l}<2 \text { years } \\
2-5 \text { years } \\
5-10 \text { years }\end{array}$} & \multirow[t]{3}{*}{3} & $16(18.6 \%)$ & $17(14.4 \%)$ & 33 & \multirow[t]{3}{*}{2.114} & \multirow[t]{3}{*}{.549} \\
\hline & & & $13(12.9 \%)$ & $10(10.1 \%)$ & 23 & & \\
\hline & & & $15(12.4 \%)$ & $7(9.6 \%)$ & 22 & & \\
\hline \multirow{4}{*}{$\begin{array}{l}\text { Kind of training for your } \\
\text { career }\end{array}$} & \multirow{4}{*}{$\begin{array}{l}\text { Driving school } \\
\text { Certificate training } \\
\text { Experience } \\
\text { others }\end{array}$} & 3 & $12(15.2 \%)$ & $15(11.8 \%)$ & 27 & 3.237 & .356 \\
\hline & & & $11(10.9 \%)$ & $6(7.4 \%)$ & 17 & & \\
\hline & & & $14(14.1 \%)$ & $11(9.6 \%)$ & 25 & & \\
\hline & & & $8(6.2 \%)$ & $3(4.8 \%)$ & 11 & & \\
\hline Key causative agents of & Drugs & 2 & $18(15.8 \%)$ & $10(12.3 \%)$ & 28 & 1.133 & .567 \\
\hline the accidents & Chewing qat & & $16(17.4 \%)$ & $15(13.6 \%)$ & 11 & & \\
\hline & Others & & $11(11.8 \%)$ & $10(9.2 \%)$ & 21 & & \\
\hline Place of car parking & On streets & 2 & $16(20.3 \%)$ & $20(15.8 \%)$ & 36 & 8.232 & .016 \\
\hline & Parking area & & $11(12.4 \%)$ & $11(9.6 \%)$ & 22 & & \\
\hline & In front of offices & & $18(12.4 \%)$ & $4(9.6 \%)$ & 22 & & \\
\hline Average driving speed in & $<20 \mathrm{~km} / \mathrm{hr}$ & 3 & $14(11.8 \%)$ & $7(9.2 \%)$ & 21 & 10.725 & .013 \\
\hline the city & $20-30 \mathrm{~km} / \mathrm{hr}$ & & $16(11.3 \%)$ & $4(8.8 \%)$ & 20 & & \\
\hline & $30-40 \mathrm{~km} / \mathrm{hr}$ & & $8(10.7 \%)$ & $11(8.3 \%)$ & 19 & & \\
\hline & Above $50 \mathrm{~km} / \mathrm{hr}$ & & $7(11.3 \%)$ & $13(8.8 \%)$ & 20 & & \\
\hline Wearing practice of a & Always & 2 & $22(15.8 \%)$ & $6(12.3 \%)$ & 28 & 9.324 & .009 \\
\hline Seat belt while & Sometimes & & $11(15.8 \%)$ & $17(12.3 \%)$ & 28 & & \\
\hline Driving & Never & & $12(13.5 \%)$ & $12(10.5 \%)$ & 24 & & \\
\hline Use mobile phone while & Always & 2 & $29(29.3 \%)$ & $23(22.8 \%)$ & 52 & 16.474 & .000 \\
\hline driving & Sometimes & & $15(14.6 \%)$ & $11(11.4 \%)$ & 26 & & \\
\hline Smoking cigarette or & r Always & 2 & $10(6.8 \%)$ & $2(5.3 \%)$ & 12 & 5.151 & .076 \\
\hline chewing chat while & Sometimes & & $20(19.7 \%)$ & $15(15.3 \%)$ & 35 & & \\
\hline driving & Never & & $15(18.6 \%)$ & $18(14.4 \%)$ & 33 & & \\
\hline How you frequent & Always & 2 & $19(19.7 \%)$ & $16(15.3 \%)$ & 35 & 14.852 & .001 \\
\hline way priorities to & Some times & & $19(19.7 \%)$ & $16(15.3 \%)$ & 35 & & \\
\hline pedestrians & Never & & $7(5.6 \%)$ & $3(4.4 \%)$ & 10 & & \\
\hline Rate pedestrians in giving & Good & 2 & $12(13.5 \%)$ & $12(10.5 \%)$ & 24 & 0.805 & .669 \\
\hline priorities to vehicles & Moderate & & $25(23.1 \%)$ & $16(17.9 \%)$ & 41 & & \\
\hline when necessary & Poor & & $8(8.4 \%)$ & $7(6.6 \%)$ & 15 & & \\
\hline Have you been stopped & & 1 & $27(24.8 \%)$ & $17(19.3 \%)$ & 44 & 4.418 & .036 \\
\hline $\begin{array}{l}\text { by traffic police for } \\
\text { violating traffic rules } \\
\text { and Regulations }\end{array}$ & $\begin{array}{l}\text { Yes } \\
\text { No }\end{array}$ & & $18(19.7 \%)$ & $17(15.3 \%)$ & 35 & & \\
\hline Rate $\quad$ traffic & Very & & $11(17.4 \%)$ & $20(13.6 \%)$ & 31 & 9.102 & .011 \\
\hline commitment to their & Good & 2 & $20(16.9 \%)$ & $10(13.1 \%)$ & 30 & & \\
\hline $\begin{array}{ll}\text { duties } & \text { and } \\
\text { Responsibilities } & \\
\end{array}$ & Poor & & $14(10.7 \%)$ & $5(8.3 \%)$ & 19 & & \\
\hline Did you got on work & Yes & 1 & $9(10.7 \%)$ & $10(8.3 \%)$ & 19 & 0.799 & .371 \\
\hline $\begin{array}{l}\text { education/training } \\
\text { about road Safety }\end{array}$ & No & & $36(34.3 \%)$ & $25(26.7 \%)$ & 61 & & \\
\hline
\end{tabular}

Source: Own data analysis result, 2021

Based on the hypothesis, as we can see from (Table 4.18) above, the $\rho$-value of the variables: educational level (0.67), drivers years that the vehicle gives the service (0.549), drivers' obtained a long career $(0.356)$, causative agents of accidents (0.567), pedestrians' manner in assigning priorities to vehicles when necessary (0.669), getting on work education/training about road safety (0.371), are more significant than the specified $\alpha$ - 
value (0.05). So, we have sufficient evidence not to reject the null hypothesis and conclude that there is no statistical association between the independent variables declared above and the occurrence of road traffic accidents. They are not statistically significant. On the other hand, the $\rho$-values for the other variables: such as drivers' age (0.028), drivers' license level (0.024), parking area of vehicles $(0.016)$, drivers approximate average driving speed (0.013), drivers giving priorities to pedestrians as required by law $(0.001)$, drivers being stopped for violating traffic rules \& regulations (0.036), using seat belts (0.009), using the mobile phone (0.000), rating traffic police commitments to their duties \& responsibilities $(0.011)$, drivers type usually drive $(0.038)$ are less than the $\alpha$-value. As a result, the null hypothesis is rejected and concluded that there is an association between road traffic accident occurrences and each of the above-stated independent variables.

Hosmer-Lemeshow Test: it assesses whether the predicted probabilities match the observed probabilities. $\mathrm{P}>$ 0.05 means the set of independent variables will accurately predict the actual probabilities of the dependent variable (Bian, 2002). Therefore, binary logistic regression models that satisfy assumptions and have model fitting statistics were chosen.

Table 3: Hosmer and Lemeshow test

\begin{tabular}{|l|c|c|c|}
\hline Step & Chi-square & Df & Sig. \\
\hline 1 & 1.977 & 8 & 0.981 \\
\hline 2 & 3.598 & 8 & 0.891 \\
\hline 3 & 5.744 & 7 & 0.570 \\
\hline
\end{tabular}

The test result from (Table 3$)$ below at the three steps $(\chi 2=5.744$ with $\mathrm{DF}=7$, and $\mathrm{p}=0.570)$ indicated that the fitted Binary logistic regression model was statistically significant, and it is possible to analyze the model further.

Results of Binary Logistic Regression Model: The results of binary logistic regression analysis are the determining powers of the independent variables on the dependent variable, the occurrence of road traffic accidents, which dominate the interaction effects among each other. This is revealed by (Table 4) below. The table indicated that the coefficients, their standard errors, the Wald test, associated p-values (Sig.), the odds, and the 95 per cent confidence interval of the coefficients. To interpret the coefficients of the predictor variables, the $\mathrm{p}$-value is compared with the $\alpha$-value $(0.05)$ level of significance. If the $\mathrm{p}$-values are $\leq 0.05$, at least one predictor is significantly associated with the response. Therefore, the results obtained can be revealed as follows: the $\mathrm{p}$-values for driving speed, age of the driver, level of license, parking area, drivers' use of mobile phones and seatbelts while driving, drivers' giving priority to pedestrians as required by law, and drivers being stopped by traffic police for violating traffic rules and regulations and rate traffic police commitment to their duties and responsibilities were less than 0.05 in the binary logistic regression model. But the $\mathrm{p}-\mathrm{values}$ for the other variables were larger than 0.05 and are not involved in the model. Thus, there was enough statistical evidence to conclude that the relationship between occurrences of road traffic accidents (Table 4.20).

Table 4. Variables in the Binary Logistic Regression Model

\begin{tabular}{|c|c|c|c|c|c|c|c|c|}
\hline \multirow[b]{2}{*}{ Variables } & \multirow[b]{2}{*}{$\mathrm{B}$} & \multirow[b]{2}{*}{ S.E. } & \multirow[b]{2}{*}{ Wald } & \multirow[b]{2}{*}{ df } & \multirow[b]{2}{*}{ Sig. } & \multirow[b]{2}{*}{$\operatorname{Exp}(B)$} & \multicolumn{2}{|c|}{$\begin{array}{l}\text { 95\% C.I.for } \\
\operatorname{EXP(B)}\end{array}$} \\
\hline & & & & & & & Lower & Upper \\
\hline Age of the driver (ref $=\mathbf{1 8 - 2 6}$ ) & 1.662 & .499 & 11.080 & 1 & .001 & 5.271 & 1.981 & 14.028 \\
\hline $\begin{array}{l}\text { Level of license } \\
\text { (ref }=\text { None) }\end{array}$ & .682 & .314 & 4.272 & 1 & .030 & 1.977 & 1.069 & 3.656 \\
\hline $\begin{array}{l}\text { Where do often park your vehicle? } \\
\text { (ref= On streets) }\end{array}$ & 1.488 & .524 & 8.054 & 1 & .005 & 4.427 & 1.584 & 12.368 \\
\hline $\begin{array}{l}\text { What is your approximate average } \\
\text { driving speed in the city (in } \mathrm{km} / \mathrm{hr} \text { ) } \\
\text { (ref= } \mathbf{2 0 - 3 0} \mathbf{~ K m} \backslash \mathbf{h r} \text { ) }\end{array}$ & -1.130 & .385 & 8.619 & 1 & .003 & .323 & .152 & .687 \\
\hline $\begin{array}{l}\text { How often did you use seat belt? } \\
\text { (ref=Sometimes) }\end{array}$ & -1.261 & .480 & 6.897 & 1 & .009 & .283 & .110 & .726 \\
\hline $\begin{array}{l}\text { Do you use mobile phone while driving? } \\
\text { (ref=Always) }\end{array}$ & -2.132 & .807 & 6.986 & 1 & .008 & .119 & .024 & .576 \\
\hline $\begin{array}{l}\text { How often did you give priorities to } \\
\text { pedestrians to pass first as required by } \\
\text { Law? (ref=Sometimes) }\end{array}$ & 1.459 & .659 & 4.908 & 1 & .027 & 4.302 & 1.183 & 15.641 \\
\hline $\begin{array}{l}\text { Have you been stopped by traffic police for } \\
\text { violating traffic rules and regulations? } \\
\text { (ref= Yes) }\end{array}$ & -1.681 & .693 & 5.876 & 1 & .015 & .186 & .048 & .725 \\
\hline $\begin{array}{l}\text { How do you rate traffic police commitment } \\
\text { to their duties and responsibilities? }\end{array}$ & & .520 & 8.244 & 1 & .004 & 4.449 & 1.606 & 12.326 \\
\hline
\end{tabular}




\begin{tabular}{|c|c|c|c|c|c|c|c|c|}
\hline \multirow[b]{2}{*}{ Variables } & \multirow[b]{2}{*}{ B } & \multirow[b]{2}{*}{ S.E. } & \multirow[b]{2}{*}{ Wald } & \multirow[b]{2}{*}{ df } & \multirow[b]{2}{*}{ Sig. } & \multirow[b]{2}{*}{$\operatorname{Exp}(B)$} & \multicolumn{2}{|c|}{$\begin{array}{l}\text { 95\% C.I.for } \\
\text { EXP(B) }\end{array}$} \\
\hline & & & & & & & Lower & Upper \\
\hline$($ ref=Good) & & & & & & & & \\
\hline Constant & -1.069 & 2.257 & .224 & 1 & .636 & .343 & & \\
\hline
\end{tabular}

\section{Source: Own data analysis, 2021}

In the logit regression model output above (Table 4), an increase in the driver's age significantly reduces the probability of falling into accidents ( $\mathrm{p}<0.001$ for a two-tailed test). The effect level of a license is significant at the 0.003 level. An increase in the level using appropriate parking places of drivers of vehicles also reduces the level of accidents significantly $(p<0.005$ level). As indicated in the study outcome, an increase in approximate average driving speed in the city and an increase in the risk of occurrence of car accidents significantly affect the probability of falling into accidents $(\mathrm{p}<0.003$ and level). In addition to that, the study discovered that using a seatbelt $(\mathrm{p}<0.009)$. Also, using a mobile phone during driving time has a significant role in a car accident $(\mathrm{p}<0.008)$.

Moreover, the study found that the drivers' priorities for pedestrians to pass first as required by law also had a significant role in the accident $(\mathrm{p}<0.027)$. Finally, the traffic police for violating traffic rules and regulations and traffic police commitment to their duties and responsibilities have a significant role in the accidents $(\mathrm{p}<$ $0.015)$ and $(p<0.004)$, respectively. Therefore, the core explanatory variables that the study took as exogenous variables have contributed to the accidents and show a substantial significant role.

Interpretation of odds ratio: Step by step analysis of the Binary logistic regression model (Table 4.20) revealed that the faults committed by drivers took a higher percentage than the other factors. Drivers do not use the seatbelt while driving, drivers use their mobile while driving, very high driving speed, violating rules and regulation of traffic safety rules, giving priority to pedestrians to pass first, less drivers who have different levels of licenses and their age.

Controlling for the other explanatory variables, the estimated odds of drivers giving priority to pedestrians to pass first as required by law was 4.302 . It indicates that the odds of giving priority to pedestrians sometimes is 4.302 more likely to the occurrences of traffic accidents than that of giving priority to pedestrians always (the reference category). Keep all the other factors constant, the estimated odds of drivers using a seat belt sometimes while driving was 0.283 . This indicates that using a seat belt sometimes. At the same time, driving is 0.283 times less likely to the occurrence of a traffic accident than that of drivers who always use a seat belt while driving (the reference category).

Keep all other independents constant. The estimated odds of 4.427 for drivers who park their vehicles near the streets indicate that 4.427 times more likely to have traffic accidents than drivers who park their vehicles in parking areas (the reference category). The estimated odds of 1.977 for drivers who did not have any license level indicates that 1.977 times to the occurrences of accidents than that of drivers who took the different level of licenses (the reference category). This result is consistent with the study done by Awoke (2018). The estimated odds of 0.119 for drivers always using the phone while driving indicates that 0.119 times less likely to occur a traffic accident than drivers not using the phone while driving (the reference category).

Keep all other factors constant. The estimated odds of 0.186 for drivers violating traffic rules and regulations indicate that 0.186 times less likely to occur a traffic accident than drivers who are not violating traffic rules and regulations (the reference category). Controlling for the other explanatory variables, the estimated odds of driver's aged 18-26 was 5.271, and it indicates that the odds of drivers aged 18-26 are 5.271 more likely to the occurrences of accidents than those of drivers aged greater than 35 years (the reference category).

Also, to control other independent variables, the estimated odds of 4.449 for a reasonable rate of traffic cop commitment, duties. In addition to that, the responsibilities mean that traffic cops who commit to their task are more likely to cause a road traffic accident than traffic cops who do not commit to their task (the reference category). The driving speed of drivers was the final determining factor in a road traffic accident in Hargeisa city. That is, the estimated odds of drivers driving between $20-30 \mathrm{~km} / \mathrm{hr}$ were 0.323 , indicating that drivers driving between $20-30 \mathrm{~km} / \mathrm{hr}$ are 0.323 times less likely to cause accidents than drivers driving faster than 50 $\mathrm{km} / \mathrm{hr}$ (the reference category).

\section{CONCLUSION AND RECOMMENDATIONS}

\subsection{Conclusion}

The goal of this study was to examine the current state of road traffic accidents in Hargeisa city, with causes of road traffic accidents. Based on the study's findings, the following conclusions were formed. The inferential statistics test results indicated that drivers were the prime responsible agents that caused road traffic accidents in the city, compared to pedestrians.

The study considered a number of factors so as to study the major causes. In the study, the driver and 
pedestrian are treated as separate groups. Among the driver factors, driving above the speed limit is a common problem in the Hargeisa city, and it's one of the causes of the rising number of accidents. The key causes of traffic accidents in Hargeisa city have been identified as driving experience, level of education, not using a cellphone while driving, and the age of taxi drivers.

In Hargeisa city, pedestrians are the road users most vulnerable to road traffic accidents. Pedestrians are because vehicle-to-pedestrian crashes are the second most common type of road traffic accident incident in Hargeisa City, next to vehicle-to-vehicle crashes. Likewise, traffic congestion causes accidents because pedestrians and cars collide on the road, and this makes the accident easier.

Road traffic accidents continued to claim lives and livelihoods in Hargeisa. It is becoming a setback for the development of Somaliland. As it claims, the most productive segments of the population. The poor are the ones who are disproportionately affected by road traffic accidents.

In conclusion, the mixed traffic flow in narrow and heavily pedestrian-movement roads, inadequate urban public transport provision, poor vehicle standards, poor maintenance and development of roads, the negligence of drivers due to lack of adequate training and driver testing, poor traffic control and enforcement, which combine to increase the risk of accidents on the roads of Hargeisa.

\subsection{Recommendations}

Based on the core findings of this study, the following are recommended:

- The government should identify the most dangerous areas of road traffic accidents in city like streets with no traffic light, narrow streets (single streets), junction points of roads and streets without square apply mandatory regular inspection, and strict control should be carried out constantly.

- Driving above the speed limit is a common problem in Hargeisa city. Therefore, strict speed control system needs to be enforced in the city by concerned bodies. In addition to these, speed control instruments should be used in the different gets of the city.

- The second most common type of road traffic accident in Hargeisa City is vehicle-to-pedestrian and vehicleto-vehicle collisions. Hence, continuous and participatory public campaigns concerning the use of roads should be given to pedestrians.

- As age of drivers increased, the occurrences of traffic accidents were decreased. Therefore, the concerned body should give priorities for age categories while giving driving license.

- The government should have a strict control system and enforcement on driver's use of seatbelt and phoning while driving.

- Finally, the writer recommended that further large prospective studies are needed to identify the possible factors associated with road traffic accidents.

\section{Referances}

Abdirisak, A. I. 2016. Somaliland Rising Accidents, The author is the English news editor of qurbejoog http://www.qurbejoog.com/somaliland-rising-road-accidents-where-lies-the-causes/.

Ahmed, M., Nimco, A., 2016. Proposal About the Causes and Solutions of Road Traffic Accidents in Hargeisa City, Somaliland. p.10.

Ahmed, S. 2013. Road Accidents : Causes \& Solutions.

NDP 2017-2021. Somaliland National Development Plan II. https://dokumen.pub/the-national-developmentplan-ii-2017-2021.html.

Haas, A. 2017. An overview of municipal finance in Hargeisa, Somaliland. International GrowthCentre.https://www.theigc.org/wpcontent/uploads/2018/01/201712HargeisaMunicipalFinanceWP_F inal2.pdf.

Diaspora 2016. Rising road accidents: Where lies the causes. Available from: http://www.qurbejoog.com/editorial-rising-road-accidents-where-lies-the-causes-by-hubaal-independentweekly-issue/.

Cochran, W. G. 1977. Sampling techniques (3rd ed.). New York: John Wiley \& Sons.

Koshin, K. 2014. Traffic Issues Facing the Country, "https://www.somalilandsun.com/somaliland-traffic-issuesfacing-the-country.

Said, A. M. 2012. Commander of Somaliland's Traffic Police department. Available from: https://reliefweb.int/report/somalia/grappling-road-accidents-toll.

Saied, A. 2019. Traffic Road Accidents And Impact of Economic Development. Available from: https://www.scribd.com/document/469092315/thesisi-book-13-8-2019-comple-pdf.

TRL 2010. Towards Safer Roads in Developing countries: A guide for planners and Engineers, TRL Overseas Development Administration, UK.

Bian H. 2002. Logistic Regression Analysis using SPSS, http://core.ecu.edu/ofe/StatisticsResearch/ found on Aug. 1, 2014. 
Awoke, M. 2018. Trends and contributing factors of road traffic accidents in Bahir Dar city, Ethiopia. Bahir Dar University.

Gabrenya K. (2003). Inferential Statistics: Basic Concepts, http://www.ask.com/question/what-are-inferentialstatistics? $\mathrm{ad}=\operatorname{dirN\& o}=2545$, found on Aug. 9, 2014.

WHO (2021). https://www.who.int/news-room/fact-sheets/detail/road-traffic-injuries.
WHO 2015.
Global
status
report
on
road
safety.

www.who.int/violence_injury_prevention/road_safety_status/2015/en. 